\title{
Colored Plastic Film Mulches Affect Tomato Growth and Yield Via Changes in Root-zone Temperature
}

\author{
Juan C. Díaz-Pérez ${ }^{1}$ and K. Dean Batal ${ }^{2}$ \\ Department of Horticulture, Coastal Plain Experiment Station - Tifton Campus, University of Georgia, \\ Tifton, Georgia 31794
}

\begin{abstract}
AdDITIONAL INDEX wORDs. heat stress, Lycopersicon esculentum, plasticulture, soil temperature
Abstract. Soil warming is one of the benefits associated with use of plastic film mulches. However, under high temperature conditions during the summer, especially in the southeastern United States, some mulches warm the soil to temperatures that might be deleterious to plant growth. Tomato (Lycopersicon esculentum Mill.) plants grown in the field were exposed to a range of root-zone temperatures (RZTs), resulting from growing the plants in different seasons and by using colored mulches that differed in their soil-warming ability. The objective was to determine the relationship of mean seasonal RZT, as affected by different colored plastic film mulches, with plant growth and fruit yield. The study consisted of experiments carried out in three seasons: Fall 1999 (five mulches, one cultivar), Spring 2000 (eight mulches and three cultivars), and Fall 2000 (four mulches and three cultivars). Treatments were black $(n=2)$, gray, red, silver $(n=3)$, and white $(n=2)$ mulches, and bare soil. Over the season, mean RZT decreased in the fall (from 32 to $\left.24^{\circ} \mathrm{C}\right)$ and increased in the spring (from 20 to $29^{\circ} \mathrm{C}$ ). Daily mean values of RZT over the season under plastic mulches were higher $\left(1\right.$ to $5^{\circ} \mathrm{C}$ ) than those of air temperature. The highest RZT at midday occurred under black mulch, and the lowest under bare soil and white mulch. Bare soil showed the largest diurnal RZT fluctuation. RZT at midday was up to $4^{\circ} \mathrm{C}$ higher under black or gray mulch compared to the other mulches or bare soil. The degree of soil warming was correlated with reflectivity of the mulch. Black mulch had the lowest light reflectance [10\% photosynthetically active radiation (PAR)] while silver mulch had the highest (55\% PAR). There were, however, differences in reflectance among mulches of the same color depending on the manufacturer. RZT affected vegetative top fresh weight (FW), fruit yield, fruit number, and individual fruit FW. All these growth attributes fitted a quadratic relationship with mean RZT for the season, with an optimal that ranged between 25.4 and $26.3^{\circ} \mathrm{C}$. The effects of colored mulches on plant response depended on the impact of the mulch on RZT. Plant growth and yield were highest as RZT approached the optimal RZT for the plants.
\end{abstract}

In the southeastern United States, most of tomato (Lycopersicon esculentum Mill.) and pepper (Capsicum annum L. var. annum) crops are produced on plastic mulch. The benefits associated with use of plastic mulches include higher yields, earlier harvests, improved weed control, and increased efficiency in the use of water and fertilizers (Lamont, 1993). Plastic mulches affect plant microclimate by modifying the soil energy balance and by restricting soil water evaporation (Liakatas et al., 1986). Modification of these microclimate factors influence soil temperature, which affects plant growth and yield (Voorhees et al., 1981). Increased root-zone temperature (RZT) is one of the main benefits associated with use of plastic mulches (Wien and Minotti, 1987). However, under conditions of high ambient temperature and high solar radiation as they occur during the summer in the southeastern United States, plants often show poor growth and low yield. Under these conditions, mulches warm the soil to

Received for publication 8 May 2001. Accepted for publication 15 Oct. 2001 Field and laboratory technical support of D. Bertrand and D. Giddings are gratefully acknowledged. We are graciously thankful to B. Mullinix for statistical assistance, and to S. Phatak, D. Granberry, J. Ruter, for reviewing the manuscript. We thank F. Blazich for editorial corrections. Thanks also to E. Folds for secretarial support, and to G. Acuña for help with field and laboratory tasks. We acknowledge support of the following donors: Asgrow, BHN, and Peto Seed for tomato seeds; United Irrigation and Roberts Irrigation Products Inc., for drip tape; Hydro Agri North America, Inc., for calcium nitrate liquid fertilizer; and GreenTek and Sonoco for plastic film mulches. Mention of trade names in this publication does not imply endorsement by the University of Georgia of products named, nor criticism of similar ones not mentioned. The cost of publishing this paper was defrayed in part by the payment of page charges. Under postal regulations, this paper therefore must hereby be marked advertisement solely to indicate this fact.

${ }^{1}$ Assistant professor and corresponding author; e-mail: jcdiaz@tifton.cpes. peachnet.edu.

${ }^{2}$ Associate professor. temperatures that may be deleterious to plant growth (Miller, 1986; Tindall et al., 1991).

Research indicates that crop responses to colored mulches are inconsistent, depending on the season, the year, and the region (Csizinszky et al., 1995). One reason for these apparent inconsistencies is that most of the mulch research is based on empirical studies where the effect of various mulches on yield is evaluated without regard to how the mulches modified the plant microenvironment (Ham et al., 1993; Tarara, 2000). Significant research during the last 30 years indicates that black mulch is recommended during the spring to warm the soil (Hatt et al., 1995; Lamont, 1993). In the summer and fall, aluminum or white colored mulches are preferred because these mulches heat the soil less than black mulch (Hatt et al., 1995; Schalk and Robbins, 1987).

In addition to soil warming, plastic mulches also modify the light environment around the plant. The light reflected from the mulch may affect plant growth and morphogenesis (Decoteau et al., 1988). However, the influence of mulch color on plant responses has been difficult to reconcile. The effect of mulch color on tomato plant growth and yield vary according to the geographic location and season (Csizinszky et al., 1995), suggesting that plants grown on colored mulches respond to factors in addition to the light reflected from the mulch.

Root-zone temperature is important in plant growth and development because it affects physiological processes in roots such as uptake of water and mineral nutrients (Cooper, 1973; Dodd et al., 2000; Tindall et al., 1990). Root-zone temperature may also be critical for plant survival, because roots have a lower temperature optimum and are less adapted to extreme fluctuations than shoots (Paulsen, 1994). Under controlled conditions, root growth increases nearly linearly with increased temperature from a minimum to an optimum temperature. Further increases in root-zone 
temperature are accompanied by a decline in root and shoot growth (Cooper, 1973; Miller, 1986; Voorhees et al., 1981). Minimum, optimum, and maximum RZTs for plant growth vary among species (Cooper, 1973). Studies at constant RZT indicate that the optimum RZT for mineral nutrient uptake and growth in tomato is between 26 and $34^{\circ} \mathrm{C}$ (Cooper, 1973; Gosselin and Trudel, 1983; Tindall et al., 1990). However, under field conditions plants are exposed to large fluctuations in air and RZTs. Thus, it is probably difficult to extrapolate plant responses in the field to plant responses under controlled environmental conditions (Voorhees et al., 1981). To our knowledge, there is no report on optimum RZTs for tomato under field conditions, although this information would be useful in tomato production on plastic mulches, as well as in the design of plastic mulches (Tarara, 2000).

In the present study, colored mulches on drip-irrigated tomato production in the field under a range of root-zone temperatures were evaluated. The objective was to determine the relationship of mean seasonal RZT, as affected by the various colored mulches, with plant growth and fruit yield. The mulches were selected to differ in their soil-warming ability and thus, to result in a range of soil temperatures under the different mulches. The effect of the mulches on air temperature was assumed to be minimal (Ham et al., 1993).

\section{Materials and Methods}

Three experiments were conducted at the Coastal Plain Experiment Station, Tifton, Ga., during Fall 1999, Spring 2000, and Fall 2000. The soil was a Tifton Sandy Loam (a fine loamy, siliceous thermic Plinthic Paleudults) with a $\mathrm{pH}$ of 6.3 to 6.7.
FALL 1999. The experimental design was a randomized complete block with five treatments (plastic mulch) and 10 replications. The mulches were gray on black (gray) (Leco, Montreal, Canada); silver on black (silver1) (Clarke Ag Plastics, Greenwood, Va.); white-on-black (white) (Leco); black mulch painted with white latex paint (white-painted); and bare soil. Black mulch was not evaluated because previous studies (Hatt et al., 1995; Schalk and Robbins, 1987) had shown that black mulch is not favorable to tomato plant growth in the fall. 'Sun Chaser' (Petoseed, Saticoy, Ca.) tomato plants were transplanted on 3 Aug. 1999.

SPRING 2000. The experimental design was a split plot with three replications, with plastic mulches $(n=8)$ as the main plot and three tomato cultivars as the subplot. The mulches used were black (black1), black-on-silver (black2) (Sonoco Products Co., Hartsville, S.C.), gray-on-black (gray) (Leco), red (red) (Sonoco), silver-on-black (silver2) (Sonoco); black mulch painted with silver paint (silver-painted); white-on-black (white) (LECO), and bare soil. The tomato cultivars used were 'Florida-91' (Asgrow, Tifton, Ga.), 'BHN-444' (BHN Research, Bonita Springs, Fla.) and 'Sun Chaser' (Petoseed). Transplanting was on 5 Apr. 2000.

FALL 2000. The experimental design was a split plot with three replications, with plastic mulches $(n=4)$ as the main plot and tomato cultivars $(n=3)$ as the subplot. The mulches used were black2, gray, and silver2, and bare soil. Even though black mulch is not recommended for tomato in the fall season, it was used to increase soil temperature and expose the plants to high RZT conditions. The tomato cultivars used were 'Heat Master', 'Heat Wave' (Petoseed), and 'Sun Chaser'. Transplanting was on 1 Aug. 2000.

Table 1. Regression parameters of RZT under mulch as a function of weeks after transplanting for various colored mulches in a tomato crop planted in three growing seasons. For regression analysis, a three parameter regression $\left[\mathrm{y}=\mathrm{a}+\mathrm{bx}+\mathrm{cx}^{2}+\mathrm{dx}^{3}\right.$ (intercept, linear, quadratic, and cubic)] was performed with PROC GLM (SAS, 2000) on RZT data (weekly means for the entire season) from each mulch.

\begin{tabular}{|c|c|c|c|c|c|c|}
\hline Mulch & Intercept $^{\mathrm{Z}}$ & Linear $^{2}$ & Quadratic & Cubic $^{z, y}$ & $\mathrm{~F}^{\mathrm{z}}$ & $\operatorname{Mean}^{\mathrm{x}}$ \\
\hline \multicolumn{7}{|c|}{ Fall 1999} \\
\hline Bare & $25.6 c^{3}(0.4)$ & -0.9 a $(0.2)$ & --- & --- & 26 & 25.6 \\
\hline Gray & $27.5 \mathrm{a}(0.4)$ & $-1.3 \mathrm{abc}(0.1)$ & $0.1 \mathrm{a}(0.1)$ & --- & 73 & 28.3 \\
\hline WhitePainted & $25.9 \mathrm{bc}(0.2)$ & $-1.5 \mathrm{bc}(0.1)$ & $0.1 \mathrm{a}(0.0)$ & $3.4 \mathrm{a}(1.1)$ & 166 & 26.8 \\
\hline Silver1 & $26.8 \mathrm{ab}(0.3)$ & $-1.1 \mathrm{ab}(0.1)$ & $0.1 \mathrm{a}(0.0)$ & --- & 108 & 27.4 \\
\hline White & $25.4 \mathrm{c}(0.2)$ & $-1.6 \mathrm{c}(0.1)$ & $0.2 \mathrm{a}(0.0)$ & $3.7 \mathrm{a}(1.1)$ & 177 & 26.5 \\
\hline SE & 0.33 & 0.14 & 0.04 & 1.1 & & \\
\hline \multicolumn{7}{|c|}{ Spring 2000} \\
\hline Bare & $25.4 \mathrm{bc}(0.6)$ & $1.2 \mathrm{a}(0.2)$ & --- & --- & 30 & 25.4 \\
\hline Black1 & $27.2 \mathrm{a}(0.5)$ & $1.1 \mathrm{a}(0.2)$ & --- & --- & 41 & 27.2 \\
\hline Black2 & $27.0 \mathrm{ab}(0.5)$ & $1.3 \mathrm{a}(0.2)$ & --- & --- & 57 & 27.0 \\
\hline Gray & $26.4 \mathrm{abc}(0.5)$ & $1.3 \mathrm{a}(0.2)$ & --- & --- & 44 & 26.4 \\
\hline Red & $27.1 \mathrm{a}(0.5)$ & $1.2 \mathrm{a}(0.2)$ & --- & --- & 47 & 27.1 \\
\hline SilverPainted & $26.3 \mathrm{abc}(0.4)$ & $1.3 \mathrm{a}(0.2)$ & --- & --- & 62 & 26.3 \\
\hline Silver2 & $26.0 \mathrm{abc}(0.5)$ & $1.3 \mathrm{a}(0.2)$ & --- & --- & 51 & 26.0 \\
\hline White & 24.8 c (0.5) & $1.5 \mathrm{a}(0.2)$ & --- & --- & 69 & 24.8 \\
\hline SE & 0.5 & 0.19 & & & & \\
\hline \multicolumn{7}{|c|}{ Fall 2000} \\
\hline Bare & 27.5 a $(0.6)$ & -1.9 c (0.4) & $0.1 \mathrm{a}(0.1)$ & 7.7 a (2.3) & 15 & 28.0 \\
\hline Black2 & 29.3 a (0.5) & $-0.8 \mathrm{ab}(0.2)$ & --- & --- & 23 & 29.3 \\
\hline Gray & 27.9 a (0.6) & $-1.7 \mathrm{bc}(0.4)$ & $0.04 \mathrm{a}(0.05)$ & $6.2 \mathrm{a}(2.2)$ & 14 & 28.3 \\
\hline Silver2 & $28.5 \mathrm{a}(0.5)$ & -0.7 a $(0.2)$ & --- & --- & 15 & 28.5 \\
\hline SE & 0.6 & 0.3 & 0.1 & 2.3 & & \\
\hline
\end{tabular}

${ }^{\mathrm{z}}$ All values were significant at $P<0.01$.

y Values shown should be divided by 100 .

xThis value is the mean of all the weekly means used in the regression analysis.

${ }^{w}$ Mean separation ( $\mathrm{n}=9$ for Fall 1999 and Spring 2000; $\mathrm{n}=10$ for Fall 2000) within columns for a season by Fisher's protected LSD at $P=0.05$. Number in parentheses represents SE. 
In all three experiments, the experimental plot consisted of an 8-m-long, 0.9-m-wide bed formed on 1.8-m centers. Before laying the mulches with a tractor, the soil was fertilized with $\mathrm{N}$, $\mathrm{P}$, and $\mathrm{K}$ at 90,90 and $54 \mathrm{~kg} \cdot \mathrm{ha}^{-1}$, respectively. The soil was fumigated with a mixture of 7 methyl bromide : 3 chloropicrin (by weight) at $250 \mathrm{~kg} \cdot \mathrm{ha}^{-1}$. Drip irrigation tape (T-Tape; T-Systems Intl., San Diego), with 30.5-cm emitter spacing and a $17-\mathrm{mL} \cdot \mathrm{min}^{-}$ ${ }^{1}$ emitter flow, was placed manually on the surface of the soil in the center of the bed. Six-week-old tomato transplants were planted to the field in a single row per bed at a $60-\mathrm{cm}$ spacing. After transplanting, $250 \mathrm{~mL}$ of starter fertilizer solution was applied directly to the base of each transplant. The starter fertilizer solution consisted of $0.72 \mathrm{~kg}$ of an $18 \mathrm{~N}-20.2 \mathrm{P}-0 \mathrm{~K}$ fertilizer mixed in $100 \mathrm{~L}$ of water. Two weeks after transplanting, plants were fertilized weekly for 8 weeks with $\mathrm{N}$ and $\mathrm{K}$ at 80 and 116 $\mathrm{kg} \cdot \mathrm{ha}^{-1}$, respectively. For both, $\mathrm{N}$ and $\mathrm{K}$, the actual rate was 1.4 $\mathrm{kg} \cdot \mathrm{ha}^{-1} \cdot \mathrm{d}^{-1}$ at early stages, $2.0 \mathrm{~kg} \cdot \mathrm{ha}^{-1} \cdot \mathrm{d}^{-1}$ during fruit development, and $1.4 \mathrm{~kg} \cdot \mathrm{ha}^{-1} \cdot \mathrm{d}^{-1}$ at late stages of development.

ROOT-ZONE TEMPERATURE, AIR TEMPERATURE, AND PHOTOSYNTHETICALLY ACTIVE RADIATION. RZT was measured by determining soil temperature midway between the plants at $10 \mathrm{~cm}$ below the mulch and the soil surface. RZT over the growing season was measured with copperconstantan thermocouples (model 107; Campbell Scientific, Logan, Utah) connected to a datalogger (CR10X; Campbell Scientific) and a relay multiplexer (AM416; Campbell Scientific). The datalogger was programmed to record readings every $10 \mathrm{~min}$ and store hourly averages for each plot. Air temperature data were obtained from a University of Georgia weather station located within $200 \mathrm{~m}$ of the plots. Incoming and reflected photosynthetically active radiation $(P A R)$ were determined with the quantum sensor of a steady state porometer (LI1600; LICOR, Lincoln, Nebr.). PAR was measured weekly for 6 weeks on clear days at 1300 to $1400 \mathrm{HR}$ from planting until plants developed full canopy. Reflected PAR was measured by placing the quantum sensor in the middle of the bed, between two plants, facing the mulch surface and at $30 \mathrm{~cm}$ above the mulch. The amount of PAR reflected by the mulches was expressed as a percentage of the incoming PAR.

HARvest. Once-over harvest was made 9 weeks after transplanting. Plants were excised at the soil level, enclosed individually in plastic bags and kept at $12{ }^{\circ} \mathrm{C}$ until their vegetative top fresh weight $(\mathrm{FW})$, fruit yield, and fruit number were determined within 24 h. Fruit yield was measured as total fruit FW per plant. Individual fruit FW was calculated as total fruit FW per plant divided by the number of fruit.

Fig. 1. Seasonal trend of root-zone and air temperatures under colored mulches during three growing seasons. Each symbol represents the weekly mean RZT under each mulch.
Statistical ANALYSIS. Data were analyzed using the Analysis of the Mixed Procedure of SAS Institute Inc. (SAS Inst. Inc., 2000). The relationships of the changes in seasonal RZT and diurnal RZT with respect to time were determined by regression analyses. A three-parameter regression (linear, quadratic, and cubic) was performed on data from each of the mulches. The equation used was $\mathrm{y}=\mathrm{a}+\mathrm{bx}+\mathrm{cx}^{2}+\mathrm{dx}^{3}$, where $\mathrm{y}$ is the measured $\mathrm{RZT}$; $\mathrm{x}$ is the deviation about the mean of $\mathrm{X}$ (diurnal: deviations about noon; seasonal: deviations about week 5); and a, b, c, and $\mathrm{d}$ are the coefficients determined by regression analysis. For seasonal relationships, the analysis was done using the daily mean value of RZT for each of the mulches during the whole season. For the diurnal relationships, the analysis was done calculating an average diurnal pattern for each of the mulches, using hourly data for the whole season.

Relationships of plant growth attributes with RZT were constructed using the means of the interaction of season, mulch and cultivar. Various models were evaluated to determine whether there was a change in the relationships of plant growth with RZT.
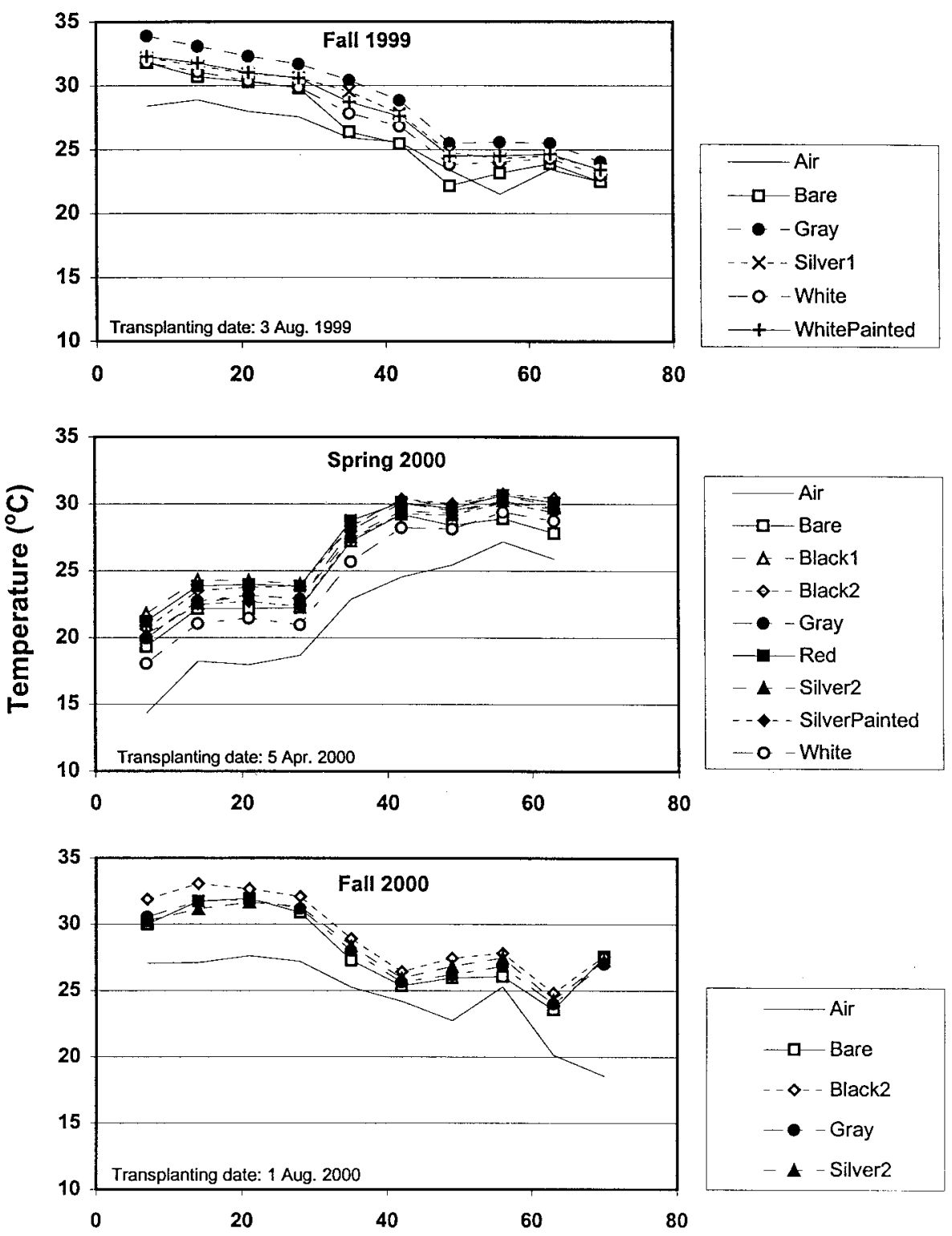

Days after transplanting 
Table 2. Regression parameters of RZT under mulch as a function of the time of the day for various colored mulches in a tomato crop planted in three growing seasons. For regression analysis, a three-parameter regression $\left[y=a+b x+c x^{2}+d^{3}\right.$ (intercept, linear, quadratic, and cubic)] was performed with PROC GLM (SAS, 2000) on the average diurnal trend (hourly means) from each mulch for the whole season.

\begin{tabular}{|c|c|c|c|c|c|c|}
\hline Mulch & Intercept $^{2}$ & Linear $^{2}$ & Quadratic & Cubic $^{z, y}$ & $\mathrm{~F}^{\mathrm{z}}$ & $\operatorname{Mean}^{\mathrm{x}}$ \\
\hline & \multicolumn{6}{|c|}{ Fall 1999} \\
\hline Bare & $26.1 \mathrm{~b}^{\mathrm{x}}(0.3)$ & $0.8 \mathrm{a}(0.1)$ & $-0.9 \mathrm{~b}(0.4)$ & $-0.6 \mathrm{~b}(0.1)$ & 51.1 & 25.6 \\
\hline Gray & $26.3 \mathrm{~b}(0.3)$ & $0.8 \mathrm{a}(0.1)$ & $-0.4 \mathrm{~b}(0.4)$ & $-0.6 \mathrm{~b}(0.1)$ & 56.8 & 28.1 \\
\hline WhitePainted & $26.7 \mathrm{~b}(0.2)$ & $0.7 \mathrm{ab}(0.1)$ & $-0.2 \mathrm{ab}(0.3)$ & $-0.5 \mathrm{~b}(0.1)$ & 64.0 & 26.2 \\
\hline Silver1 & $27.5 \mathrm{a}(0.1)$ & $0.4 \mathrm{c}(0.0)$ & $0.6 \mathrm{a}(0.2)$ & -0.3 a (0.1) & 47.7 & 27.8 \\
\hline White & $26.6 \mathrm{~b}(0.2)$ & $0.6 \mathrm{~b}(0.1)$ & $-0.7 \mathrm{~b}(0.3)$ & $-0.5 \mathrm{~b}(0.1)$ & 72.7 & 26.2 \\
\hline \multirow[t]{2}{*}{$\mathrm{SE}$} & 0.2 & 0.1 & 0.3 & 0.1 & & \\
\hline & \multicolumn{6}{|c|}{ Spring 2000} \\
\hline Bare & $25.7 \mathrm{~b}(0.3)$ & $1.0 \mathrm{a}(0.1)$ & $-0.6 \mathrm{~b}(0.5)$ & -0.8 c $(0.1)$ & 101.6 & 25.9 \\
\hline Black1 & 27.0 a $(0.2)$ & $1.0 \mathrm{a}(0.1)$ & $0.4 \mathrm{a}(0.4)$ & -0.8 bc $(0.1)$ & 120.1 & 27.1 \\
\hline Black2 & $27.0 \mathrm{a}(0.2)$ & $0.9 \mathrm{ab}(0.1)$ & $0.1 \mathrm{ab}(0.3)$ & -0.7 bc $(0.1)$ & 135.0 & 26.9 \\
\hline Gray & $26.2 \mathrm{~b}(0.2)$ & $0.8 \mathrm{bc}(0.1)$ & $0.5 \mathrm{a}(0.3)$ & $-0.6 \mathrm{ab}(0.1)$ & 125.6 & 26.3 \\
\hline Red & 27.0 a (0.3) & $1.0 \mathrm{a}(0.1)$ & $0.3 \mathrm{ab}(0.4)$ & -0.8 bc $(0.1)$ & 104.9 & 27.0 \\
\hline SilverPainted & $25.9 \mathrm{~b}(0.2)$ & 0.7 c (0.0) & 0.8 a $(0.2)$ & -0.6 a $(0.0)$ & 165.5 & 26.2 \\
\hline Silver2 & $25.7 \mathrm{~b}(0.2)$ & 0.7 c (0.0) & 0.8 a (0.3) & -0.5 a (0.0) & 138.5 & 26.0 \\
\hline White & $24.4 \mathrm{c}(0.2)$ & $0.6 \mathrm{c}(0.0)$ & 0.8 a (0.2) & -0.5 a (0.0) & 138.7 & 24.7 \\
\hline \multirow[t]{2}{*}{ SE } & 0.2 & 0.1 & 0.3 & 0.1 & & \\
\hline & \multicolumn{6}{|c|}{ Fall 2000} \\
\hline Bare & $29.2 \mathrm{ab}(0.4)$ & $1.0 \mathrm{a}(0.1)$ & $-2.2 \mathrm{~b}(0.7)$ & $-0.8 \mathrm{~b}(0.1)$ & 45.4 & 28.0 \\
\hline Black2 & $29.8 \mathrm{a}(0.3)$ & $0.9 \mathrm{ab}(0.1)$ & -0.7 a $(0.5)$ & $-0.7 \mathrm{ab}(0.1)$ & 66.4 & 29.4 \\
\hline Gray & $28.6 \mathrm{~b}(0.2)$ & $0.7 \mathrm{c}(0.1)$ & $-0.4 \mathrm{a}(0.3)$ & $-0.5 \mathrm{a}(0.1)$ & 68.3 & 28.4 \\
\hline Silver2 & $29.0 \mathrm{ab}(0.3)$ & $0.7 \mathrm{bc}(0.1)$ & -0.8 a $(0.4)$ & $-0.6 \mathrm{ab}(0.1)$ & 54.4 & 28.5 \\
\hline $\mathrm{SE}$ & 0.3 & 0.1 & 0.5 & 0.1 & & \\
\hline
\end{tabular}

${ }^{\mathrm{z}}$ All values were significant at $P<0.01$.

yValues shown should be divided by 100 .

xThis value is the mean of all the weekly means used in the regression analysis.

wMean separation $(\mathrm{n}=63)$ within columns for a season by Fisher's protected LSD at $P=0.05$. Number in parentheses represents SE.

\section{Results}

SEASONAL AND DIURNAL TRENDS IN RZT. The rate of change in RZT over the season was primarily linear (Table 1). In the mulches where the change in RZT over the season was quadratic or cubic, there was still a strong linear effect. Mean RZT for all mulches declined from $32^{\circ} \mathrm{C}$ at transplanting to $24^{\circ} \mathrm{C}$ at harvest time during both fall growing seasons (Fig. 1). In Fall 1999, the rate of RZT decrease was linear for bare soil, gray and silver1 mulch, and cubic for the other mulches (Table 1). In Fall 2000, the rate of RZT decrease was linear for black2 and silver2, and cubic for bare and gray mulch (Table 1 ). The linear rate of RZT decrease ranged from 0.9 to $1.6^{\circ} \mathrm{C} /$ week in Fall 1999, and from 0.7 to 1.9 ${ }^{\circ} \mathrm{C} /$ week in Fall 2000. In Spring 2000, mean RZT increased (from 20 to $29^{\circ} \mathrm{C}$ ) linearly for all mulches. The linear rate of RZT increase was similar among treatments (range: 1.2 to $1.5{ }^{\circ} \mathrm{C} /$ week). Gray, silver-painted, silver2, and white mulches had the lowest intercept. The intercept in this case was the mean RZT at midseason (week 5). In the fall, mean RZT was 3 to $4{ }^{\circ} \mathrm{C}$ higher than in the spring (Table 1). Mean RZT was highest on black1, black2, and red mulches and lowest on white mulch and bare soil (Table 1). Mean RZT under the mulches was higher than mean air temperature by $2{ }^{\circ} \mathrm{C}$ (white, silver1) to $5^{\circ} \mathrm{C}$ (black1, black2).

On a diurnal basis, the rate of change in RZT over time fitted a cubic relationship (Table 2, Fig. 2). The rate of change in RZT varied among mulches, as indicated by their differences in linear and cubic parameters (Table 2). Low linear or high cubic values indicate that RZT declined substantially at night and in the morning, and that the mulch had a low soil-warming ability. High linear or low cubic values indicate that RZT changed little at night and there was a rapid increase in RZT during the day (i.e., mulch had a high soil-warming ability). The quadratic component was small and thus had a small effect on the RZT vs. time relationship.

During the three seasons, bare soil and dark mulches (black1, black2, and red) had a higher soil-warming ability (i.e., a higher linear value) compared to the light-colored mulches (silver1, silver-painted, silver2, and white). The soil-warming ability of gray mulch was intermediate between dark and light-colored mulches. The diurnal trends in RZT of all mulches were similar to each other, except that of Silver1, which showed less diurnal fluctuations in RZT (Fig. 2). Silver1 warmed the soil at a lower rate (linear was lower) but it retained the heat longer (i.e., cubic was smaller) than the other mulches. Bare soil retained less heat than soil covered with plastic mulches.

The highest RZT at midday occurred under black1, black2, red, and gray mulches and the lowest under bare soil and white mulch (Fig. 2, Table 2). Midday RZT under black1, black2, red, or gray mulch was up to $4{ }^{\circ} \mathrm{C}$ higher than in bare soil or white mulch. During the night, the range in RZT among mulches was $\leq 1.5^{\circ} \mathrm{C}$, with the exception of silver1 mulch, which showed a higher RZT than the other mulches.

During the day, the range in RZT among mulches tended to increase with increasing air temperature. On a diurnal basis, RZT under plastic mulches was 1 to $5{ }^{\circ} \mathrm{C}$ higher than air temperature. Silver1 showed the smallest diurnal fluctuation in RZT (Fig. 2). RZT under silver1 mulch was the highest during the night and one of the lowest at midday. Bare soil showed the largest diurnal fluctuation in RZT. 

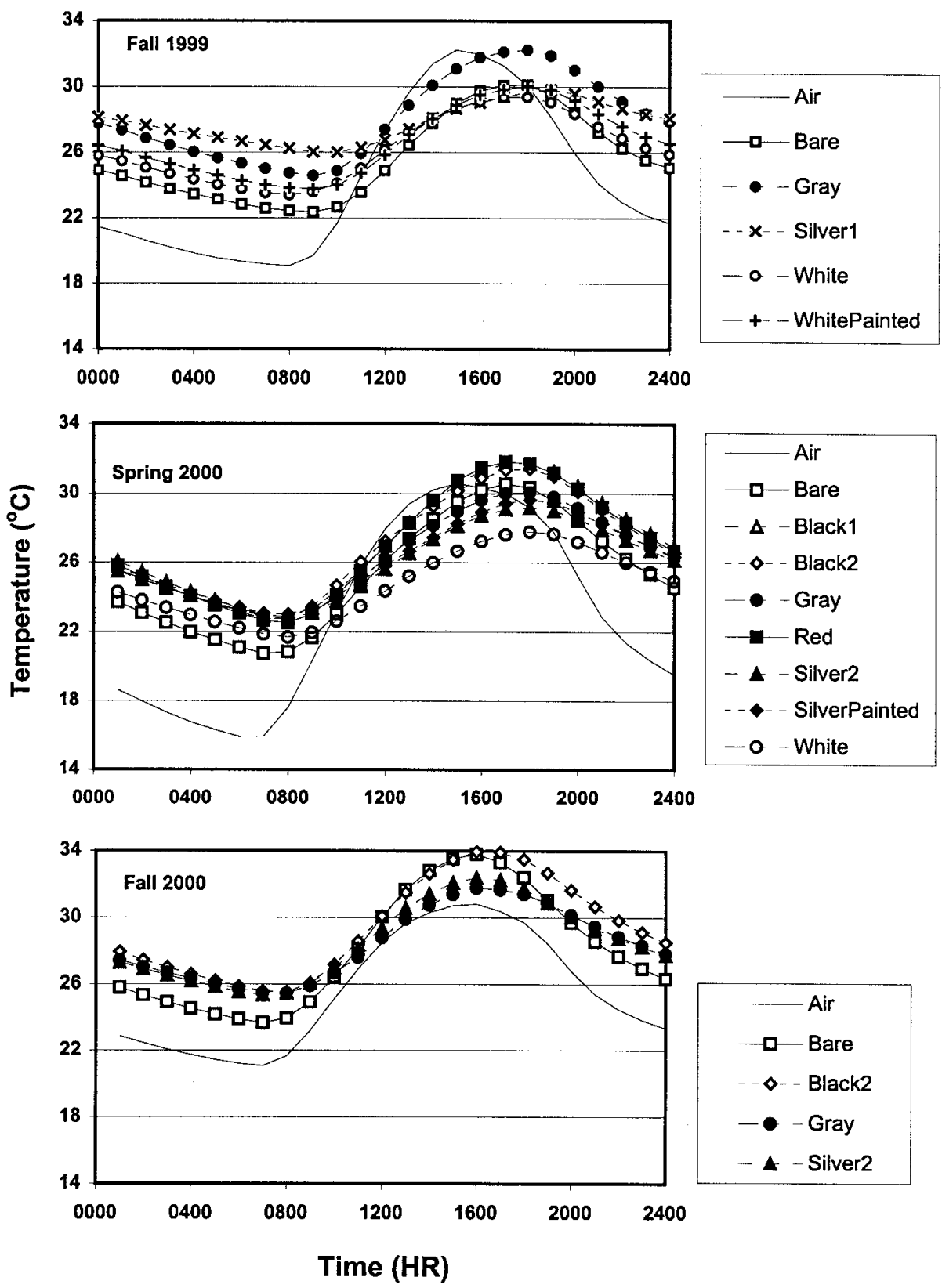

Fig. 2. Diurnal trends in root-zone and air temperature under colored mulches during three growing seasons. Each symbol represents the hourly mean RZT for the entire season.

In the fall, the minimum RZT occurred at 0600 to $0800 \mathrm{HR}$ (Eastern Standard Time) and the maximum was reached at 1600 to $1700 \mathrm{HR}$. During the spring, minimum RZT was at $0800 \mathrm{HR}$ and the maximum at 1730 to $1900 \mathrm{HR}$ (Fig. 2). The minimal and maximal values were calculated by solving the quadratic equation that resulted from the derivative of the cubic relationship of RZT vs. time of the day (Table 2).

Plastic mulches differed widely in the amount of light (PAR) they reflected. Even mulches of similar color (e.g., silver1 and silver2) differed in their light-reflecting properties (Fig. 3). Under high irradiance conditions $\left(>1,900 \mathrm{mmol} \cdot \mathrm{m}^{-2} \cdot \mathrm{s}^{-1}\right)$, black 1 and black2 reflected the least $P A R(10 \%)$, and silver1 reflected the most $(55 \%$ PAR). Bare soil reflected $12 \%$ of PAR (data not presented). Data from the three seasons indicate that the amount of light reflected from the colored mulches was inversely corre- lated with the RZT under the mulches. Because the slope calculated from Fall 1999 data was not statistically different to that from Fall 2000 data, a single regression curve was fitted by pooling all fall data (Fig. 3). The reflected $P A R$ vs. RZT relationship calculated from the fall data indicated that $P A R$ reflection explained $70 \%(\mathrm{y}=-0.0505 \mathrm{x}$ $\left.+30.076 ; r^{2}=0.702 ; \mathrm{F}=0.018\right)$ of the differences in RZT among mulches, while the relationship from the spring data showed that $P A R$ reflection explained $53 \%(\mathrm{y}=-$ $\left.0.0353 \mathrm{x}+27.307 ; r^{2}=0.528 ; \mathrm{F}=0.0645\right)$ of the differences in RZT. The slope of the fall $(-0.0505 ; \mathrm{SE}=0.0147)$ and spring $(-0.0353$; $\mathrm{SE}=0.0149)$ relationships were not statistically different. However, the intercept of the fall $(30.076 ; \mathrm{SE}=0.528)$ was higher than the intercept of the spring $(27.307 ; \mathrm{SE}=0.477)$, probably because the mean seasonal RZT were higher in the fall than in the spring. The intercept value is thus highly dependent on the temperature conditions in the field. The intercept in this case is equivalent to the RZT in the absence of $P A R$ reflection from the mulch.

EFFECT OF MULCH AND CULTIVAR ON PLANT GROWTH AND FRUIT YIELD. There were differences in vegetative top FW and fruit yield among fall and spring seasons (Tables 3, 4, and 5). In both fall seasons (Tables 3 and 5), plant FW and fruit yields were lower than in the spring (Table 4). Within the same season, there were also differences in vegetative top FW and fruit yield among mulches or cultivars. No mulch $\times$ cultivar interaction was found (Tables 4 and 5). In Fall 1999, growth and fruit yield of plants on bare soil were similar to those of plants on lightcolored mulches (Table 3). However, in Fall 2000 , values for growth and yield of plants on bare soil were the lowest (Table 5). Thus, plants on either bare soil or gray mulch showed contrasting results in the two fall seasons. During the fall seasons, vegetative top FW and fruit yield were highest in plants grown on light-colored mulches (Tables 3 and 5). In the spring, vegetative top FW and fruit yield were highest in plants on dark mulches (Table 4).

RELATIONSHIP OF RZT WITH PLANT GROWTH AND YIELD. Pooled data from the three seasons indicated that vegetative top $\mathrm{FW}$, fruit yield, individual fruit $\mathrm{FW}$, and fruit number fit a quadratic relationship with the mean seasonal RZT (Fig. 4). Quadratic equations in Fig. 4 were used to compute the maximum and optimum RZT for plant growth and yield. Maximum RZT values were calculated by solving the quadratic equation for $\mathrm{y}=0$ from the sampled data. The optimum RZT for plant growth and yield was calculated by setting the first derivative of the equations equal to 0 . The predicted optimum temperatures were $25.4{ }^{\circ} \mathrm{C}$ (vegetative top $\mathrm{FW}$ ), $26.3^{\circ} \mathrm{C}$ (fruit yield), $25.8^{\circ} \mathrm{C}$ (individual fruit $\mathrm{FW}$ ) and $26.3{ }^{\circ} \mathrm{C}$ (fruit number), with a mean optimum (average of the four optimum values) of $26^{\circ} \mathrm{C}$ for the tomato plant. The predicted maximum RZT above which no growth 


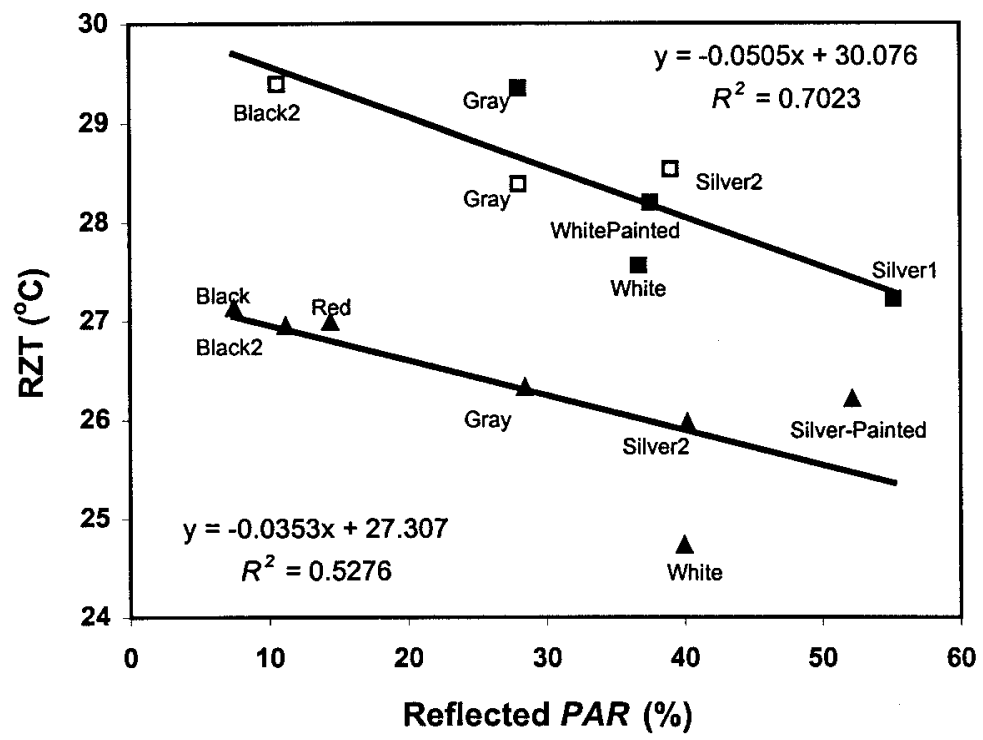

Fig. 3. Relationship of root-zone temperature (RZT) under mulch with the photosynthetically active radiation $(P A R)$ reflected by the mulch. Each symbol represents a mean of reflected $P A R\left(\mu \mathrm{mol} \cdot \mathrm{m}^{-2} \cdot \mathrm{s}^{-1}\right)$ and RZT measurements made on each experimental unit twice a week for 6 weeks. Average incident $P A R$ for the season was $1900 \mu \mathrm{mol} \cdot \mathrm{m}^{-2} \cdot \mathrm{s}^{-1}$. Solid lines were fitted by linear regression. Bare soil was not included in the relationship.

Table 3. Effect of colored mulches on vegetative top fresh weight (FW) and fruit FW and fruit yield of 'Sunchaser' tomato grown in the Fall 1999 season.

\begin{tabular}{|c|c|c|c|c|}
\hline Mulch & $\begin{array}{c}\text { Top FW } \\
\text { (kg/plant) }\end{array}$ & $\begin{array}{l}\text { Fruit FW } \\
\text { (kg/fruit) }\end{array}$ & $\begin{array}{c}\text { Fruit no./ } \\
\text { plant }\end{array}$ & $\begin{array}{c}\text { Fruit yield } \\
\text { (kg/plant) }\end{array}$ \\
\hline Bare & $1.04 \mathrm{a}^{\mathrm{z}}$ & $0.05 \mathrm{a}$ & $20.0 \mathrm{ab}$ & $1.24 \mathrm{ab}$ \\
\hline Gray & $0.49 \mathrm{~b}$ & $0.02 \mathrm{~b}$ & $3.7 \mathrm{~b}$ & $0.08 \mathrm{~b}$ \\
\hline Painted & $0.66 \mathrm{ab}$ & $0.02 \mathrm{~b}$ & $14.8 \mathrm{ab}$ & $0.47 \mathrm{ab}$ \\
\hline Silver1 & $1.10 \mathrm{a}$ & $0.05 \mathrm{a}$ & $27.7 \mathrm{a}$ & $1.59 \mathrm{a}$ \\
\hline White & $0.89 \mathrm{ab}$ & $0.06 \mathrm{a}$ & $21.0 \mathrm{ab}$ & $1.29 \mathrm{ab}$ \\
\hline \multicolumn{5}{|c|}{ Significance of F test ${ }^{\mathrm{y}}$} \\
\hline Mulch & 0.0007 & 0.001 & 0.008 & $<0.0001$ \\
\hline
\end{tabular}

${ }^{\mathrm{z}}$ Mean separation $(\mathrm{n}=20)$ within columns by Fisher's protected LSD test at $P \leq 0.05$.

${ }^{\mathrm{y}} P$ values for mulch effect.

Table 4. Effect of colored mulch and cultivar on vegetative top FW, fruit FW, and fruit yield of tomato grown in the Spring 2000 season.

\begin{tabular}{|c|c|c|c|c|}
\hline Treatment & $\begin{array}{c}\text { Top FW } \\
\text { (kg/plant) }\end{array}$ & $\begin{array}{l}\text { Fruit FW } \\
\text { (kg/fruit) }\end{array}$ & $\begin{array}{c}\text { Fruit no./ } \\
\text { plant }\end{array}$ & $\begin{array}{c}\text { Fruit yield } \\
\text { (kg/plant) }\end{array}$ \\
\hline \multicolumn{5}{|l|}{ Cultivar } \\
\hline BHN-444 & $1.37 \mathrm{a}^{\mathrm{z}}$ & $0.06 \mathrm{a}$ & $45.1 \mathrm{a}$ & $2.79 \mathrm{a}$ \\
\hline FL-91 & $1.40 \mathrm{a}$ & $0.05 \mathrm{~b}$ & $30.7 \mathrm{c}$ & $1.80 \mathrm{c}$ \\
\hline Sun Chaser & $1.34 \mathrm{a}$ & $0.06 \mathrm{~b}$ & $35.7 \mathrm{~b}$ & $2.14 \mathrm{~b}$ \\
\hline \multicolumn{5}{|l|}{ Mulch } \\
\hline Bare & $1.35 \mathrm{~b}$ & $0.06 \mathrm{a}$ & $26.9 \mathrm{~b}$ & $1.56 \mathrm{~b}$ \\
\hline Black1 & $1.38 \mathrm{~b}$ & $0.06 \mathrm{a}$ & $40.3 \mathrm{a}$ & $2.45 \mathrm{a}$ \\
\hline Black2 & $1.26 \mathrm{~b}$ & $0.06 \mathrm{a}$ & $38.6 \mathrm{a}$ & $2.35 \mathrm{a}$ \\
\hline Gray & $1.39 \mathrm{a}$ & $0.06 \mathrm{a}$ & $46.2 \mathrm{a}$ & $2.83 \mathrm{a}$ \\
\hline Red & $1.23 \mathrm{~b}$ & $0.06 \mathrm{a}$ & $42.9 \mathrm{a}$ & $2.63 \mathrm{a}$ \\
\hline Silver2 & $1.41 \mathrm{~b}$ & $0.06 \mathrm{a}$ & $40.6 \mathrm{a}$ & $2.46 \mathrm{a}$ \\
\hline SilverPainted & $1.74 \mathrm{a}$ & $0.06 \mathrm{a}$ & $38.1 \mathrm{a}$ & $2.31 \mathrm{a}$ \\
\hline White & $1.19 \mathrm{~b}$ & $0.05 \mathrm{~b}$ & $23.7 \mathrm{~b}$ & $1.34 \mathrm{~b}$ \\
\hline \multicolumn{5}{|c|}{ Significance of $\mathrm{F}$ test $^{\mathrm{y}}$} \\
\hline Cultivar (C) & 0.635 & $<0.0001$ & $<0.0001$ & $<0.0001$ \\
\hline Mulch (M) & 0.005 & 0.002 & 0.003 & 0.002 \\
\hline $\mathrm{C} \times \mathrm{M}$ & 0.342 & 0.164 & 0.143 & 0.158 \\
\hline
\end{tabular}

zMean separation $(\mathrm{n}=15)$ within columns for cultivar or mulch by Fisher's protected LSD test at $P \leq 0.05$.

${ }^{\text {y }} P$ values for cultivar and mulch effects. 
Table 5. Effect of colored mulch and cultivar on vegetative top FW, fruit FW, and fruit yield of tomato grown in the Fall 2000 season.

\begin{tabular}{|c|c|c|c|c|}
\hline Treatment & $\begin{array}{c}\text { Top FW } \\
\text { (kg/plant) }\end{array}$ & $\begin{array}{l}\text { Fruit FW } \\
\text { (kg/fruit) }\end{array}$ & $\begin{array}{c}\text { Fruit no./ } \\
\text { plant }\end{array}$ & $\begin{array}{c}\text { Fruit yield } \\
\text { (kg/plant) }\end{array}$ \\
\hline \multicolumn{5}{|l|}{ Cultivar } \\
\hline Heat Master & $0.28 \mathrm{a}^{\mathrm{z}}$ & $0.04 \mathrm{a}$ & $14.4 \mathrm{a}$ & $0.58 \mathrm{a}$ \\
\hline Heat Wave & $0.26 \mathrm{a}$ & $0.04 \mathrm{a}$ & $10.6 \mathrm{~b}$ & $0.47 \mathrm{a}$ \\
\hline Sun Chaser & $0.30 \mathrm{a}$ & $0.04 \mathrm{a}$ & $9.1 \mathrm{~b}$ & $0.47 \mathrm{a}$ \\
\hline \multicolumn{5}{|l|}{ Mulch } \\
\hline Bare & $0.11 \mathrm{~b}$ & $0.02 \mathrm{c}$ & $4.6 \mathrm{~b}$ & $0.08 \mathrm{c}$ \\
\hline Black2 & $0.19 \mathrm{~b}$ & $0.04 \mathrm{~b}$ & $9.4 \mathrm{~b}$ & $0.34 \mathrm{~b}$ \\
\hline Gray & $0.40 \mathrm{a}$ & $0.06 \mathrm{a}$ & $15.2 \mathrm{a}$ & $0.82 \mathrm{a}$ \\
\hline Silver & $0.41 \mathrm{a}$ & $0.05 \mathrm{a}$ & $16.3 \mathrm{a}$ & $0.79 \mathrm{a}$ \\
\hline \multicolumn{5}{|c|}{ Significance of $\mathrm{F}$ test $\mathrm{t}^{\mathrm{y}}$} \\
\hline Cultivar (C) & 0.476 & 0.619 & 0.001 & 0.252 \\
\hline Mulch (M) & 0.003 & 0.003 & 0.004 & 0.0003 \\
\hline $\mathrm{C} \times \mathrm{M}$ & 0.442 & 0.904 & 0.250 & 0.960 \\
\hline
\end{tabular}

${ }^{\overline{\mathrm{Z}}}$ Mean separation $(\mathrm{n}=15)$ within columns for cultivar or mulch by Fisher's protected LSD $(P \leq 0.05)$.

top $\mathrm{FW}$ and fruit $\mathrm{FW}$ by $18 \%$. A $3{ }^{\circ} \mathrm{C}$ increase in $\mathrm{RZT}$ above the optimal resulted in negligible fruit yield and fruit number, while vegetative top FW and individual fruit FW were reduced by $31 \%$.

\section{Discussion}

Results indicate that growth of tomato was highly related to the RZT under mulch. Tomato vegetative top FW and individual fruit FW, fruit number or fruit yield were highest as the seasonal mean RZT under mulch approached the calculated optimal RZT for each growth attribute $\left(25.4\right.$ to $\left.26.3^{\circ} \mathrm{C}\right)$. To our knowledge, this is the first report on determination of optimal RZT for tomato under field conditions.

Under controlled-temperature conditions, optimal RZT for tomato shoot growth and fruiting is about $30^{\circ} \mathrm{C}$ (Cooper, 1973; Gosselin and Trudel, 1983). In a growth chamber study, the optimal temperature for tomato root and shoot $\mathrm{DW}$ and uptake for the majority of mineral nutrients was at $25^{\circ} \mathrm{C}$ (Tindall et al., 1990). However, plant responses under constant RZT may differ from the responses of plants grown under changing RZT as occurs diurnally and seasonally in the field (Cooper, 1973; Voorhees et al., 1981). Our data indicated that in the fall, daily mean RZT declined from $32^{\circ} \mathrm{C}$ at transplanting to $24^{\circ} \mathrm{C}$ at harvest time, while in the spring, mean daily RZT increased from 20 to 29 ${ }^{\circ} \mathrm{C}$ over the growing season (Fig. 1). Thus, particularly during the early stages of development, tomato plants were exposed to more days at RZTs above the optimal in the fall than in the spring, which probably explains the lower values of vegetative top FW and fruit yield in the fall compared to the spring. On a diurnal basis, tomato plants experienced RZT changes of $\leq 10^{\circ} \mathrm{C}$ in both fall and spring seasons. These large diurnal RZT changes indicate that there were times of the day when plants were exposed to RZTs above the optimal.

Fig. 4. Relationships of root-zone temperature (RZT) under mulch with tomato vegetative top $\mathrm{FW}$, fruit yield, individual fruit $\mathrm{FW}$, and fruit number. Graphs were constructed with data from the Fall 1999 (five mulches, one cultivar), Spring 2000 (eight mulches, three cultivars), and Fall 2000 (four mulches, three cultivars) seasons. Each symbol represents the mean growth or yield and mean seasonal RZT for a given mulch and tomato cultivar. Solid lines were fitted by linear regression. Regression equations: fruit FW, $\mathrm{y}=-2.5863 \mathrm{x}^{2}+134.19 \mathrm{x}-$ $1680\left(r^{2}=0.46, \mathrm{~F}=8.80, P=0.005\right)$; fruit number, $\mathrm{y}=-3.6867 \mathrm{x}^{2}+193.71 \mathrm{x}-$ $2508.8\left(r^{2}=0.55, \mathrm{~F}=18.8, P=0.0001\right)$; fruit yield, $\mathrm{y}=-0.2555 \mathrm{x}^{2}+13.428 \mathrm{x}-$ $174.2\left(r^{2}=0.56, \mathrm{~F}=20.0, P<0.0001\right)$; vegetative top $\mathrm{FW}, \mathrm{y}=-0.0867 \mathrm{x}^{2}+$ $4.3865 \mathrm{x}-54.061\left(r^{2}=0.75, \mathrm{~F}=14.0, P=0.0006\right)$.
There were significant differences in soil-warming ability among mulches. Regression analysis showed that over the season, dark mulches (black, gray, and red) had a higher linear value,
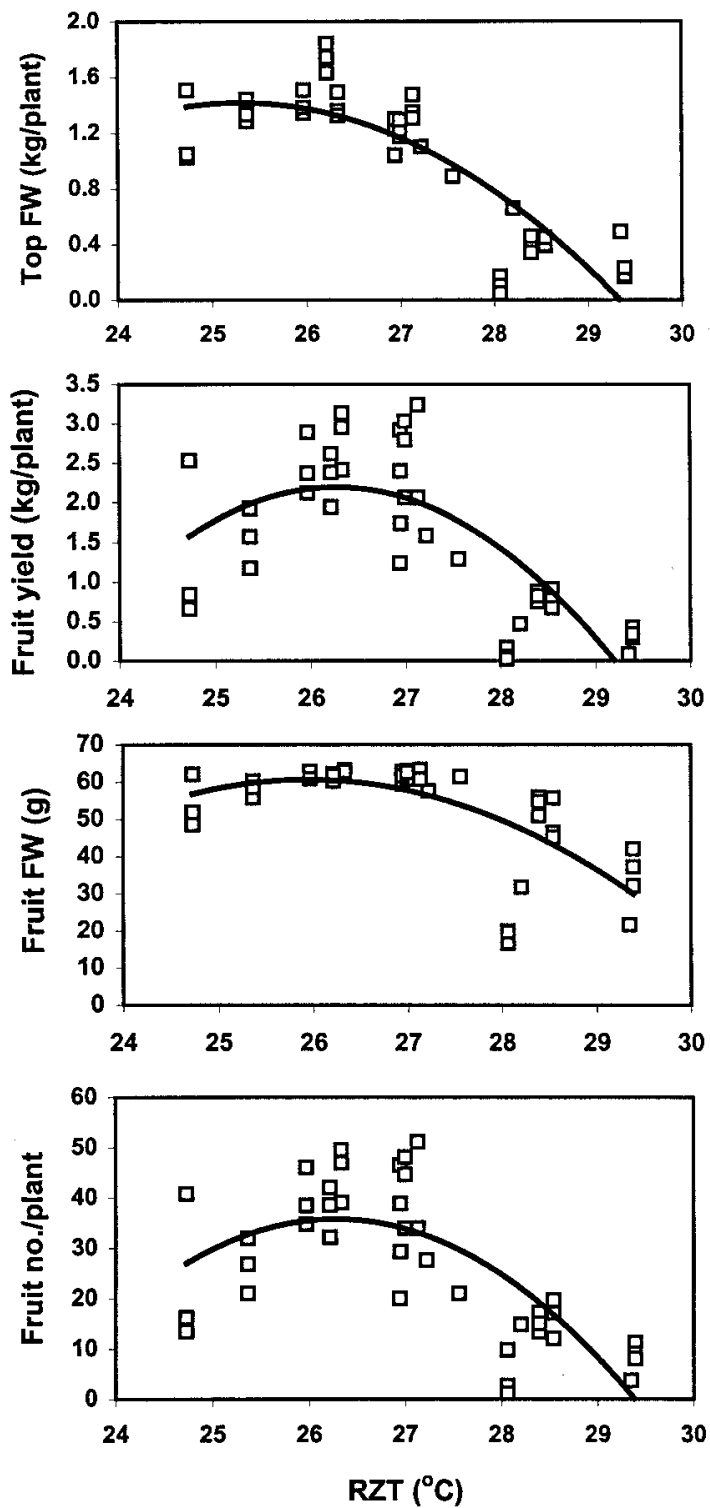


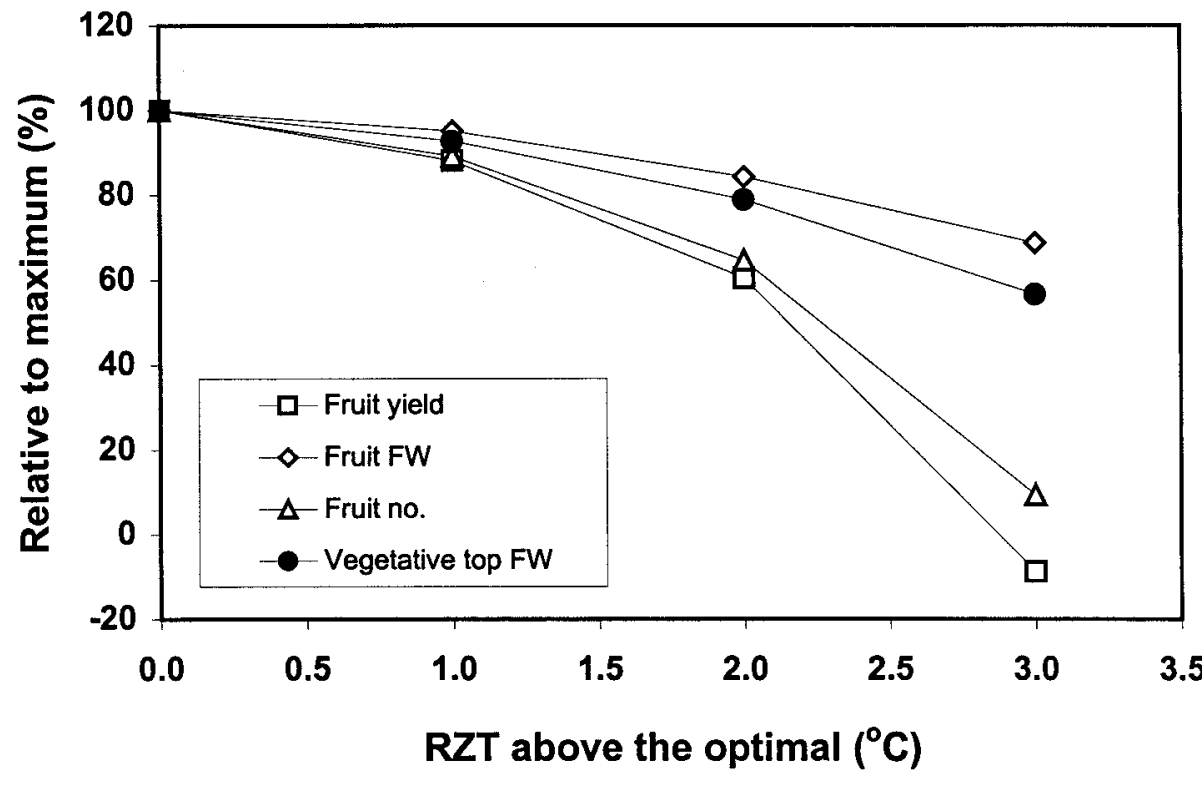

Fig. 5. Model of the effect of root-zone temperature (RZT) above the optimal for tomato growth and yield. Values of fruit yield $(\mathrm{kg} / \mathrm{plant})$, individual fruit FW (kg/fruit), fruit number, and vegetative top FW (kg) were calculated from the equations in Fig. 4 and are expressed as a percentage relative to the maximum value for each growth attribute. Optimal RZT values used in the model were $25.8^{\circ} \mathrm{C}$ (individual fruit $\mathrm{FW}$ ), $26.3^{\circ} \mathrm{C}$ (fruit number), $26.3^{\circ} \mathrm{C}$ (fruit yield), and $25.4{ }^{\circ} \mathrm{C}$ (vegetative top $\mathrm{FW}$ ). Optimal RZT values were calculated from the equations in Fig. 4.

compared to light-colored mulches. This indicates that dark mulches had a higher soil-warming ability than light-colored mulches. Dark mulches also maintained higher values of RZT relative to light-colored mulches or bare soil. On a diurnal basis, bare soil and dark mulches warmed the soil faster than lightcolored mulches, as indicated by their higher linear and cubic values compared to light-colored mulches (Table 1).

Increased warming ability of the dark mulches was beneficial in the spring. Under cool conditions, dark mulches maintained RZTs closer to the optimal for longer periods of time compared to light colored mulches. Thus, tomato plant growth and yield were higher under dark mulches compared to light-colored mulches. This phenomenon has been recognized since the beginning of plastic mulch utilization (Lamont, 1993). In contrast to the spring, in the fall, when the natural soil-warming pattern is reversed, RZT under light-colored mulches was closer to the optimal compared to the dark mulches. Thus, under warm conditions, plants under light-colored mulches had higher values of vegetative top FW and yield compared to plants under dark mulches.

Under controlled conditions, the general response curve of tomato shoot growth with RZT is sigmoidal both, below and above the optimal RZT. However, the change in shoot DW with each unit change in RZT above the optimal is steeper than below it (Cooper, 1973). Our field results indicated that vegetative top FW and fruit growth and yield fit a quadratic relationship with RZT under mulch, and there was a rapid decline in growth and yield as the RZT increased above the optimal. The calculated value of maximum RZT for growth and yield was only 3.0 to 4.5 ${ }^{\circ} \mathrm{C}$ higher than the optimal. This indicates that tomato plant growth and yield can be reduced drastically even when plants are exposed to RZT only slightly higher than the optimal RZT. We were unable to quantify the effect of RZT below the optimal because of insufficient data. However, it is possible that below the optimal, the slope of the growth response vs. RZT relationship is less steep than above the optimal. Previous reports indicate that minimal RZT for tomato is about $10^{\circ} \mathrm{C}$. Thus, it is possible that small reductions in RZT relative to the optimal do not have a significant impact on plant growth and yield.

Little is known about the effect of high RZTs on plant growth and function. High RZTs can have a drastic effect on vegetative top growth, fruiting, water and mineral nutrient uptake, assimilate partitioning, and root respiration (Cooper, 1973; Dodd et al., 2000; Tindall et al., 1990). Different organs may also differ in their sensitivity to RZT, as in greenhouse-grown tomato plants where the optimal RZT for shoot dry matter production is $24^{\circ} \mathrm{C}$ and that for roots is $26^{\circ} \mathrm{C}$ (Tindall et al., 1990). In the present study, tomato fruit number was more sensitive to the increases in RZT above the optimal than either vegetative top FW or fruit FW. Fruit number and individual fruit FW both determine plant yield. Thus, the decrease in yield was attributed primarily to reductions in fruit number. In several agronomic crops, root temperature stress has been found to influence anthesis and seed development (Zobel, 1992). Reithmann (1933), as reported by Cooper (1973), found that at constant RZT tomato fruit number, fruit size, and fruit yield respond similarly to $\mathrm{RZT}$, with an optimal at 30 to $35^{\circ} \mathrm{C}$.

Our results demonstrated that RZT was also associated with the amount of light reflected from the mulches. Dark-colored mulches were warmer than light-colored mulches. However, the data indicated that the general term of mulch 'color' is inadequate because mulches with the same color differed in their light reflecting properties and thus they differed in their respective RZT. This may explain the apparent poor consistency of results among several reports on colored mulches. For instance, there were differences in bell pepper yield when plants were grown on red mulch with different optical properties, from five different manufacturers (Orzolek and Otjen, 1996). Mulches may affect root-zone temperature by factors other than reflected light, such as light transmittance and absorbtance of the mulch, bed width, and the degree of contact between soil and mulch et al., 1993)" (Ham et al., 1993).

The majority of reports suggest that colored mulches influence plant growth and yield primarily through modification of the light environment around the plant (Kasperbauer, 1992). Red mulches reflect far red light and thus modify the red:far red ratio and phytochrome action in plants (Decoteau et al., 1988; Kasperbauer, 1992; Kasperbauer and Hunt, 1998). Kasperbauer and Hunt (1998) found that tomato plants on red mulch yield more than those on black mulch and concluded that increased yield was caused by reflection of far red light to the plants. These authors determined that RZT under black mulch $\left(\approx 27.9^{\circ} \mathrm{C}\right)$ was 0.2 to 0.9 higher that under red mulch, and concluded the differences in RZT between mulches had a minor effect on tomato yield. However, it is possible those differences in RZT were not minor since, according to our model, relatively small RZT increases can have substantial reductions in yield as RZT deviates above the optimal. From mean daily RZT, calculated from the morning and midday data of Kasperbauer and Hunt (1998), our model predicts 
that a $0.5^{\circ} \mathrm{C}$ difference between the red $\left(27.4{ }^{\circ} \mathrm{C}\right)$ and the black $\left(27.9^{\circ} \mathrm{C}\right)$ mulches results in a yield difference of about $15 \%$. Thus, in addition to the light effects, possibly colored mulches modify RZT in ways that may significantly influence plant growth and yield.

RZT as affected by mulches can have a major impact on plant growth and yield but under certain conditions, such as high insect pressure, other factors may be of greater importance. In Spring and Fall 2000, there was a higher incidence of silverleaf whiteflies (Bemisia argentifolii Bellows \& Perring), western flower thrips (Frankliniella occidentallis Pergande) and Tomato spotted wilt virus in plants grown in bare-soil relative to those on plastic mulch (Diaz-Perez, personal observation). Thus, from the thermal point of view, bare soil may be a better option than certain colored mulches during high-temperature conditions. However, bare soil may result in increased incidence of insects and vectortransmitted diseases. In addition, colored mulches have been shown to affect plant growth and yield by modifying insect behavior (Decoteau et al., 1988; Schalk and Robbins, 1987).

In conclusion, colored mulches had a positive or negative effect on tomato plant growth and yield depending on the soilwarming conditions in different seasons. Use of color as a mulch descriptor may be insufficient to predict how plants will respond when grown on colored plastic mulches. Information on the optical and thermal properties of the mulch and the impact of those properties on the RZT will likely contribute to better predicting crop response when grown on colored plastic film mulches.

\section{Literature Cited}

Cooper, A.J. 1973. Root temperature and plant growth-A review. Commonwealth Agr. Bureaux, Slough, U.K.

Csizinszky, A.A., D.J. Schuster, and J.B. Kring. 1995. Color mulches influence yield and insect pest populations in tomatoes. J. Amer. Soc. Hort. Sci. 120:778-784.

Decoteau, D.R., M.J. Kasperbauer, D.D. Daniels, and P.G. Hunt. 1988. Plastic mulch color effects on reflected light and tomato plant growth. Scientia Hort. 34:169-175.

Dodd, I.C., J. He, C.G. N. Turnbull, S.K. Lee, and C. Critchley. 2000. The influence of supra-optimal root-zone temperatures on growth and stomatal conductance in Capsicum annuum L. J. Expt. Bot. 51:239248.

Gosselin, A. and M.J. Trudel. 1983. Interaction between air and root temperatures on greenhouse tomato: I. Growth, development, and yield. J. Amer. Soc. Hort. Sci. 108:901-905.
Ham, J.M., G.J. Kluitenberg, and W.J. Lamont. 1993. Optical properties of plastic mulches affect the field temperature regime. J. Amer. Soc. Hort. Sci. 118:188-193.

Hatt, H.A., D. Decoteau, and D.E. Linvill. 1995. Development of a polyethylene mulch system that changes color in the field. HortScience 30:265-269.

Kasperbauer, M.J. 1992. Phytochrome regulation of morphogenesis in green plants: From the Beltsville spectrograph to colored mulch in the field. Photochem. Photobiol. 56:823-832.

Kasperbauer, M.J. and P.G. Hunt. 1998. Far-red light affects photosynthate allocation and yield of tomato over red mulch. Crop Sci. 38:970974.

Lamont, Jr., W.J. 1993. Plastic mulches for production of vegetable crops. HortTechnology 3:35-39.

Liakatas, A., J.A. Clark, and J.L. Monteith. 1986. Measurements of the heat balance under plastic mulches. Agr. Forest Meteorol. 36:227-239.

Miller, D.E. 1986. Root systems in relation to stress tolerance. HortScience 21:963-970.

Orzolek, M.D. and L. Otjen. 1996. Is there a difference in red mulch? Proc. 26 Natl. Agr. Plastic Congr. 26:164-171.

Paulsen, G.M. 1994. High temperature responses of crop plants, p. 365389. In: K.J. Boote, J.M. Bennett, T.R. Sinclair, and G.M. Paulsen (eds.). Physiology and determination of crop yield. Amer. Soc. of Agron., Madison, Wis.

Riethmann, O. 1933. Der einfluss der bodentemperatur auf das wachstum und die reifezeit der tomaten. Ber. Schweiz. Bot. Ges. 42:152-168.

SAS Institute Inc. 2000. SAS/C OnlineDoc. Release 7.00. SAS Inst. Inc., Cary, N.C.

Schalk, J.M. and M.L. Robbins. 1987. Reflective mulches influence plant survival, production, and insect control in fall tomatoes. HortScience 22:30-32.

Tarara, J.M. 2000. Microclimate modification with plastic mulch. HortScience 35:169-180.

Tindall, J.A., R.B. Beverly, and D.E. Radcliffe. 1991. Mulch effect on soil properties and tomato growth using micro-irrigation. Agron. J. 83:1028-1034.

Tindall, J.A., H.A. Mills, and D.E. Radcliffe. 1990. The effect of rootzone temperature on nutrient uptake of tomato. J. Plant Nutr. 13:939956.

Voorhees, W.B., R.R. Allmaras, and C.E. Johnson. 1981. Alleviating temperature stress, p. 217-266. In: G.F. Arkin and H.M. Taylor (eds.). Modifying the root environment to reduce crop stress. Monogr. 4 Amer. Soc. of Agr. Eng., St. Joseph, Mich.

Wien, H.C. and P.L. Minotti. 1987. Growth, yield, and nutrient uptake of transplanted fresh-market tomatoes as affected by plastic mulch and initial nitrogen rate. J Amer. Soc. Hort. Sci. 112:759-763.

Zobel, R.W. 1992. Soil environment constraints to root growth. Adv. Soil Sci. 19:27-51. 